\title{
MODERN FEATURES OF CHICKEN POX COURSE IN ADULTS
}

Olha Volobuieva, Tetiana Liadova, Tetiana Sevastianova, Daniil Volobuiev

V. N. Karazin Kharkiv National University, 6 Svobody Sq., Kharkiv, 61022, Ukraine,

e-mail: med@karazin.ua

The article presents the epidemiological and clinical data of the modern course of chickenpox. A high incidence among adults with a bright manifestation of the clinical picture was shown. Recurrent episodes of chicken pox were marked.

KEY WORDS: VZV, chicken pox, epidemic process, clinical picture, adults

\section{СУЧАСНІ ОСОБЛИВОСТІ ПЕРЕБІГУ ВІТРЯНОЇ ВІСПИ У ДОРОСЛИХ}

\section{Волобуєва О. В., Лядова Т. І., Севаст'янова Т. В., Волобуєв Д. А.}

Харківський національний університет імені В. Н. Каразіна, пл. Свободи, 6, м. Харків, 61022, Україна

У статті представлені епідеміологічні та клінічні дані сучасного перебігу вітряної віспи. Показана висока захворюваність серед дорослого населення 3 яскравою маніфестацією клінічної картини. Відзначено повторні епізоди вітряної віспи.

КЛЮЧОВІ СЛОВА: VZV, вітряна віспа, епідемічний процес, клініка, дорослі

\section{СОВРЕМЕННЫЕ ОСОБЕННОСТИ ТЕЧЕНИЯ ВЕТРЯНОЙ ОСПЫ У ВЗРОСЛЫХ}

Волобуева О. В., Лядова Т. И., Севастьянова Т. В., Волобуев Д. А.

Харьковский национальный университет имени В. Н. Каразина, пл. Свободы, 6, г. Харьков, 61022, Украина

В статье представлены эпидемиологические и клинические данные современного течения ветряной оспы. Показана высокая заболеваемость среди взрослого населения с яркой манифестацией клинической картины. Отмечены повторные эпизоды ветряной оспы.

КЛЮЧЕВЫЕ СЛОВА: VZV, ветряная оспа, эпидемический процесс, клиника, взрослые

\section{INTRODUCTION}

Chickenpox is a disease with global prevalence. 80-90 million cases of chickenpox are registered worldwide every year. The incidence of varicella remains stably high with small variations over the years and is determined by the presence of acquired immunity in the population. In the European Region, chickenpox is also characterized by a high intensity of the epidemic process. The incidence rates were: in Spain - 2.5-5.5\%, France $-1000-1350 \%$, Slovenia $-770.0 \%$, in Latvia $-277.9 \%$, in Estonia - $580.8 \%$, the Netherlands $-253.5 \%$ [1]. In addition, in the last decade there has been a tendency to an increase in the incidence rate in Ukraine [2]. According to experts, in the near future in

(C) Volobuieva O. V., Liadova T. I.,
Ukraine there may be a large-scale epidemic of chickenpox [3].

The current epidemic process of chickenpox is characterized by the tendency of «maturity» of the infection, especially among the urban population. Every year from 5 to $6 \%$ of cases are diseases among adults. Seroepidemiological studies show regional differences in the proportion of susceptible adults [4]. Some studies has shown that there was a remarkable increase in the incidence rate of chickenpox in middle and older age groups till 2014 and before chickenpox and shingles vaccination [5-7]. Varicella zoster has also been associated with elevated risk for cerebrovascular disease and contributes to vasculopathy that is especially important matter in adults [8-9]. Despite the low incidence of chickenpox in adults, the risk of severe 
complications and even death is 10-20 times higher than in children. Most often the disease is benign, but in 1 out of 50 cases of the disease there are complications, the most severe are pneumonia and encephalitis among them. The incidence of encephalitis, which is predominantly manifested by cerebral ataxia, is about 1 in 4000 cases of chicken pox. Pneumonia can be both primary viral and bacterial in nature [10-11].

The significance of chickenpox is also determined by the presence of a chronic recurrent form of the infection - shingles, the frequency of which is about 70 per 100,000 people who have had chickenpox. The Varicella-Zoster virus (VZV) is epitheliotropic and neurotropic, but it is also possible to generalize the process with damage to the internal organs: liver, lungs, and gastrointestinal tract [12-14]. The most important risk factors associated with the severity of varicella, generalization of the process and death are age and impaired function of the immune system [15-17].

\section{OBJECTIVE}

The aim of this study is to assess the increase in the chickenpox incidence and the current course of the disease among the adult population of the Kharkiv region on the basis of hospitalization data from 2015 to 2018 years.

\section{MATERIALS AND METHODS}

There were 174 patients with diagnosed chickenpox under our supervision, who were hospitalized in the Regional Clinical Infectious Diseases Hospital during the period from 2015 to 2018. The median age of the examined patients was $23 \pm 5.8$ years. Gender analysis showed the prevalence of males - $106(61 \%)$ men versus $68(39 \%)$ women. This distribution among the adult population is explained by varicella outbreaks among military personnel living in barracks $-42(24 \%)$ cases. The diagnosis was established on the basis of clinical, epidemiological data and was confirmed by serological and molecular genetic techniques. Serological studies were performed by the method of enzyme-linked immunosorbent assay (ELISA) with the detection of specific antibodies, IgM (qualitative) and $\operatorname{IgG}$ (quantitative), to the antigens of the VZV. Molecular genetic studies of samples for the detection of presence of VZV DNA were carried out by PCR with hybridization-fluorescence detection of results in real time.

\section{RESULTS AND DISCUSSION}

$162(93.1 \pm 3.8 \%)$ patients among the 174 observed had contact with chickenpox patients. In particular, 15 people had contact with sick children $(9.2 \pm 0.4 \%)$, at the work place -21 people $(12.9 \pm 4.6 \%), 138$ patients $(85.2 \pm$ $5.9 \%)$ were hospitalized not only according to clinical, but also epidemiological indications: persons living in hostels and military personnel hospitalized from barracks where varicella outbreaks were recorded; in 12 cases $(6.9 \pm$ $0.4 \%$ ), no direct contact with patients with chicken pox was detected. Thus, the majority of patients had direct contact with patients with chickenpox during the height of the disease, that is, during the period of the greatest infectiousness of patients. At the same time, an important role belongs to close contact (accommodation in hostels, barracks). Recurrent chickenpox disease was diagnosed in $12(6.9 \%)$ patients, the interval between these episodes ranged from 5 to 12 years. In this group of patients the clinical course of the disease did not have any features. There was a characteristic winter-spring seasonality of chicken pox with a maximum frequency of seeking medical help in March, December, January (fig. 1).

Chickenpox in adults is characterized by a longer prodromal period, if it is 24-72 hours in children, then in adults it can reach 7-10 days, thereby making it difficult to timely diagnose and increasing the risk of infection of contact persons. The prodromal period in our patients lasted for $2.5 \pm 1.5$ days and was characterized by an increase in temperature of $38.7 \pm 1.3{ }^{\circ} \mathrm{C}$, general weakness, decreased performance, lethargy, and drowsiness in all patients. An increase in body temperature was observed on the first day of the disease - in $108(62.3 \pm$ $5.7 \%)$ patients. However, this symptom appeared on the second day of the disease in 41 $(23.6 \pm 4.7 \%)$ patients, on the 3-4th day of the disease in $17(9.8 \pm 2.7 \%)$, and it was shortterm for one day in $8(4,6 \pm 0.7 \%)$ patients (temperature rise to $37.2 \pm 0.5^{\circ} \mathrm{C}$ ). Clinical manifestations of the prodromal period are presented in fig. 2. 


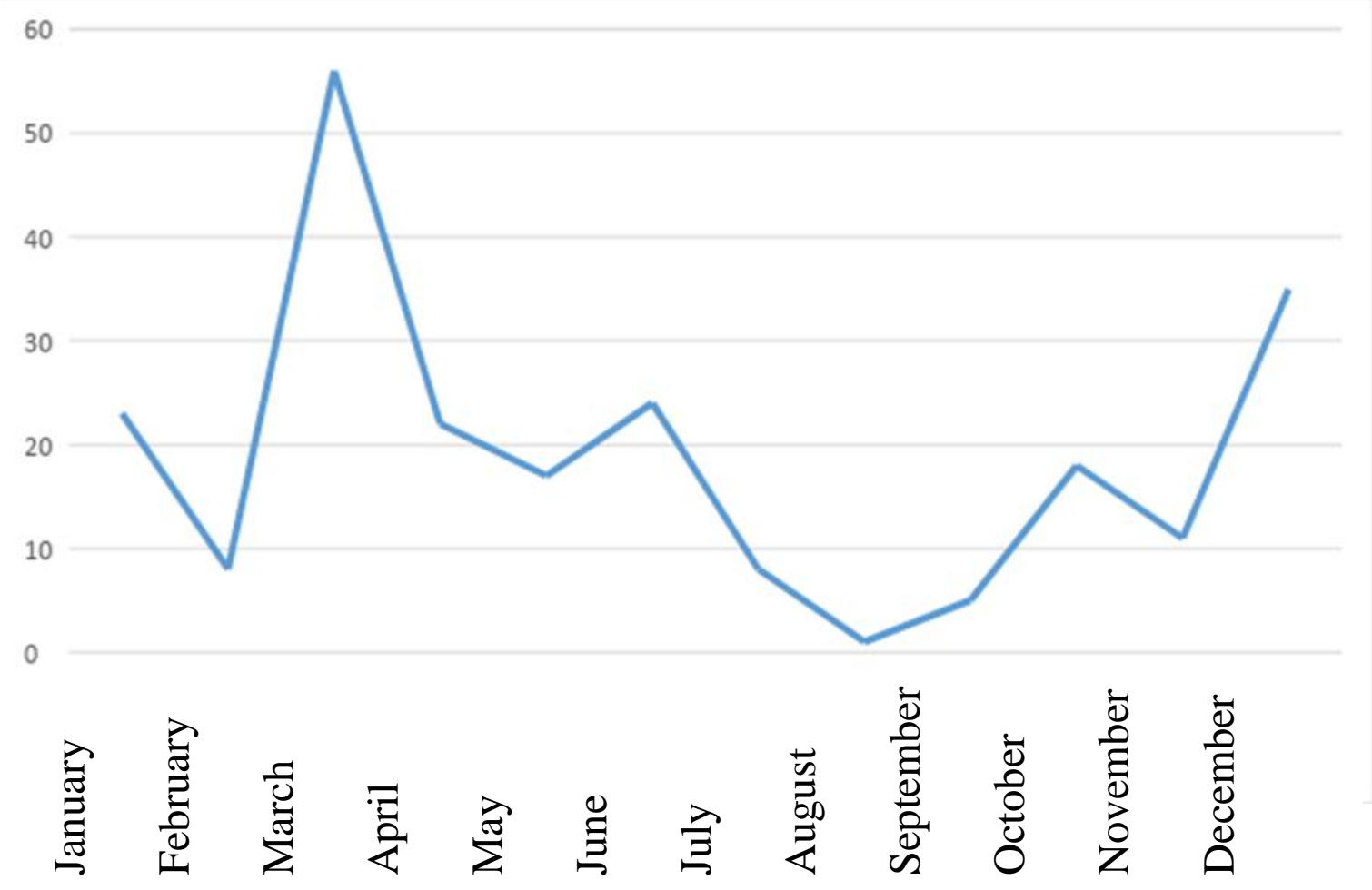

Fig. 1. Dynamics of incidence of chickenpox depending on seasonality

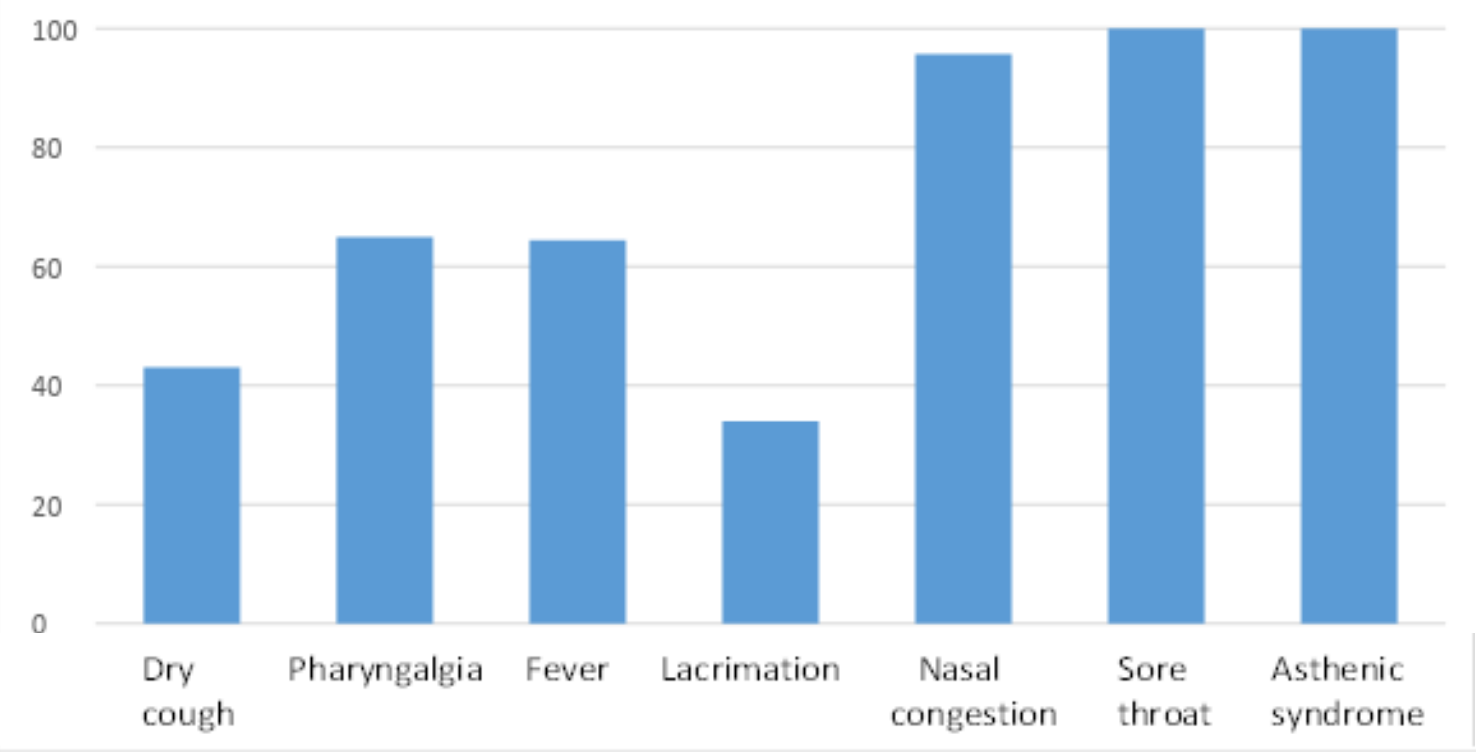

Fig. 2. Clinical manifestations of the chickenpox prodromal period in adults

Hospitalization of $139 \quad(80.1 \pm 5.0 \%)$ patients was carried out during the rash on the 2-3rd day of illness. However, hospitalization of $6(12.8 \pm 4.0 \%)$ patients was noted and in the later stages of the disease - on the 4-5th day. The period of rash began predominantly with the appearance of several spottypapullosis elements, which were localized on the face and scalp (48.5\%), in the ear areas $(22.8 \%)$ or simultaneously on the scalp and behind the ear $(28.5 \%)$. In the next $1-4$ days, the rash began to spread to the neck, torso, 
upper and lower extremities. At the same time, the rash was scanty on the lower limbs in $131(75.3 \pm 5.2 \%)$ patients. Within a few hours, the rash acquired the character of vesicles with transparent contents. These rashes were characterized by the phenomenon of pouring in addition, while in every second patient the rash was accompanied by skin itch. The rash became polymorphic - spottypapular-vesicular on the 3-4th day from the beginning of the appearance of the first elements, then gradually began to dry out with the formation of crusts, which completely fell away on the $7^{\text {th }}-12$ th day. The rash was abundant in $45(25.9 \pm 5.7 \%)$ patients. A distinctive feature of the rash was rapid and abundant pustulization, which was observed in almost half of the patients (54.3 \pm $5.9 \%)$. Pustalization was accompanied by a significant $\left(39-40^{\circ} \mathrm{C}\right)$ rise in temperature, and in $14(20 \%)$ patients pyoderma was so pronounced that it required additional antibacterial therapy, and in 7 cases the disease had severe coarse of the disease associated with the severity of pyoderma. It should also be noted that the period of rash was accompanied by intoxication and astenovegetative syndromes: severe headache, malaise and weakness in $100 \%$ of patients. The febrile period lasted $6.0 \pm 2.0$ days in uncomplicated cases, with the development of complications that continued to $9.0 \pm 2.0$ days. Usually, the temperature returned to normal with the end of the period of pouring. Catarrhal phenomena were observed in all patients at the height of the disease. So, the mucosa of the oropharynx was vividly hyperaemic in $84(48.3 \pm 5.2 \%)$ patients, moderate hyperaemia was observed in 58 $(33.3 \pm 4.6 \%)$, and weak - in $32(18.4 \pm$ $5.9 \%$ ) patients, at the same time the granularity of the tonsils, palatine arches and posterior pharyngeal wall was observed in all patients. The exanthema was accompanied by exanthema on the oral mucosa, mainly in the palatal arches and the soft palate, in 80 (45.6 $\pm 5.8 \%$ ) patients. Exanthema initially had the appearance of bright pink papules, and then turned into bubbles, which quickly opened to form sores, covered with a white and yellow patina. Stomatitis developed, causing severe pain while eating. Rashes were observed on the conjunctiva in 63 patients $(36.2 \pm 5.6 \%)$, which was accompanied by the development of scleritis and conjunctivitis during the 3 5 days period of the rash. The disease was accompanied by lymphadenopathy with an increase in the cervical $(57.1 \pm 5.9 \%)$ and occipital $(42.8 \pm 5.9 \%)$ lymph nodes in 161 $(92.5 \pm 3.1 \%)$ patients.

Etiotropic therapy included acyclovir (85\% of cases) both in case of primary infection and in repeated cases of the disease. Antibacterial drugs (third generation of cephalosporins, penicillins, macrolides) were prescribed in case of the additional bacterial complications.

\section{CONCLUSIONS}

The modern course of varicella in Ukraine is characterized by an increase in the incidence among the adult population. Infection is manifested by a long prodromal period, a pronounced intoxication syndrome, lymphadenopathy, and an abundant polymorphic rash. At the same time, the rash had a pustular character in $54.3 \%$ of patients; exanthema was observed with scleritis and conjunctivitis in $45 \%$ of cases. There are repeated cases of chickenpox, the interval between these episodes ranged from 5 to 12 years.

\section{PERSPECTIVES FOR FUTURE STUDIES}

Taking into account the epidemiological situation in the country it remains relevant to study main features of the course of chickenpox in individuals against the background of pulmonary tuberculosis, depending on the age and duration of the underlying disease.

\section{REFERENCES}

1. Distribution of varicella-zoster virus (VZV) wild-type genotypes in northern and southern Europe: evidence for high conservation of circulating genotypes / V. N. Loparev [et al.] // Virology. - 2009. - Vol. 383. - P. 216-225.

2. Predotvrashhenie vetrjanoj ospy sredstvami specificheskoj profilaktiki v Belarusi, Kazahstane. Rossii i Ukraine (zajavlenie gruppy jekspertov $\mathrm{v}$ oblasti vakcinoprofilaktiki)/A.A. Baranov [i dr.]// Pediatricheskaja farmakologija. - 2008. - T. 5, No. 3. - S. 6-14. 
3. NETWORK - A Co-operation Project for Communicable Disease Control in Northern Europe http://www.epinorth.org/Varicella

4. Helmuth, Ida Glode, et al. "Varicella in Europe - a review of the epidemiology and experience with vaccination». Vaccine 33.21 (2015): 2406-2413.

5. Sallam, Mohamed, Shazia Nadeem, and Nanda Kumar. «Epidemiological situation of chickenpox in Qatar (2012-2014)». Journal of Emergency Medicine, Trauma and Acute Care 2016.2 (2016): 5.

6. Public Health Agency of Canada. 2016. Active vaccines: herpes zoster (shingles) vaccine. Available at https://www.canada.ca/en/public-health/services/publications/healthy-living/canadianimmunization-guidepart-4-active-vaccines/page-8-herpes-zoster-(shingles)-vaccine.html.

7. Widgren, Katarina, et al. «The burden of chickenpox disease in Sweden». BMC infectious diseases 16.1 (2016): 666.

8. Nagel, Maria A., Dallas Jones, and Ann Wyborny. «Varicella zoster virus vasculopathy: the expanding clinical spectrum and pathogenesis». Journal of neuroimmunology 308 (2017): 112-117.

9. Breuer, Judith, et al. «Herpes zoster as a risk factor for stroke and TIA A retrospective cohort study in the UK». Neurology 83.2 (2014): e27-e33.

10. Sinha, Arijit, et al. «Acute disseminated encephalomyelitis in chicken pox». National Journal of Medical Research 6.1 (2016): 103-104.

11. Weber, David M., and Joseph A. Pellecchia. «Varicella pneumonia: study of prevalence in adult men». Clinical Infectious Diseases 66.3 (2018): iii-iv.

12. Radon-Proskura, Julia, et al. «Visceral varicella-zoster virus (VZV) infection as an underestimated differential diagnosis of acute abdomen in a patient after allogeneic hematopoietic stem cell transplantation». Acta Haematologica Polonica 48.4 (2017): 372-377.

13. S. Nageswaramma, G. Swarna Kumari, and Bala Kumar Dorai. «Hemorrhagic varicella». Indian Journal of Paediatric Dermatology 19.2 (2018): 143.

14. González-Motos, Víctor, et al. «Varicella zoster virus glycoprotein C increases chemokine-mediated leukocyte migration». PLoS pathogens 13.5 (2017): e1006346.

15. Kanwaria, Dharmendra, Y. C. Porwal, and Manish Kumar. «Acute appendicular perforation: A rare complication of chickenpox in an immunocompetent adult». Edorium Journal of Surgery 3 (2016): 1-5.

16. Ong, Chong Yau, et al. «Incidence and mortality rates of varicella among end stage renal disease (ESRD) patients in Singapore General Hospital, a 12-year review». BMC infectious diseases 18.1 (2018): 118.

17. Fairchild, J. Kaci, Kari A. Haws, and Christie Mead. «The Aging Body and Age-Related Health Conditions». Psychology of Aging: A Biopsychosocial Perspective (2017): 1772. 